\title{
Artefak Litik Ceruk Layah, Sampung : Kajian Teknoekonomi
}

\section{Indah Asikin Nurani}

Keywords: stone tools, lithics, cave, settlement, subsistence, prehistory, typology

\section{How to Cite:}

Nurani, I. A. (2003). Artefak Litik Ceruk Layah, Sampung : Kajian Teknoekonomi. Berkala Arkeologi, 23(1), 12-27. https://doi.org/10.30883/jba.v23i1.857

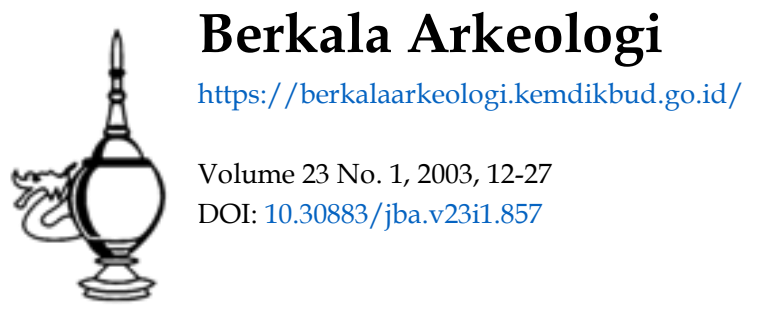

\section{c) (1) (2)}

This work is licensed under a Creative Commons Attribution-NonCommercial-ShareAlike 4.0 International License. 


\title{
ARTEFAK LITIK CERUK LAYAH, SAMPUNG : KAJIAN TEKNOEKONOMI
}

\author{
Indah Asikin Nurani
}

\section{$\mathbf{P}$} endahuluan

Ceruk Layah merupakan salah satu ceruk hunian masa prasejarah yang berada pada kawasan perbukitan kapur di Kecamatan Sampung, Ponorogo. Sampung, dalam kalangan arkeolog bukan nama baru lagi, karena di lokasi ini ditemukan Gua Lawa yang memiliki karakter khas berupa industri alat tulang yang dikenal dengan budaya Sampung. Berdasarkan hal tersebut, maka Balai Arkeologi Yogyakarta melakukan penelitian di kawasan perbukitan kapur ini untuk mengetahui potensi budaya utamanya pada gua atau ceruk sekitar Gua Lawa.

Ceruk Layah terletak di sebelah barat Gua Lawa berjarak sekitar $312.5 \mathrm{~m}$. yang merupakan sebuah ceruk berukuran dalam $5.40 \mathrm{~m}$, panjang $15.80 \mathrm{~m}$, dengan tinggi atap $3.70 \mathrm{~m}$, terletak pada satuan batuan batugamping kalkarinit berlapis dari Formasi Sampung. Ceruk ini merupakan hasil dari pengikisan atau erosi air permukaan setelah satuan batuan batugamping mengalami pengangkatan yaitu sekitar Kala Meosen Atas.

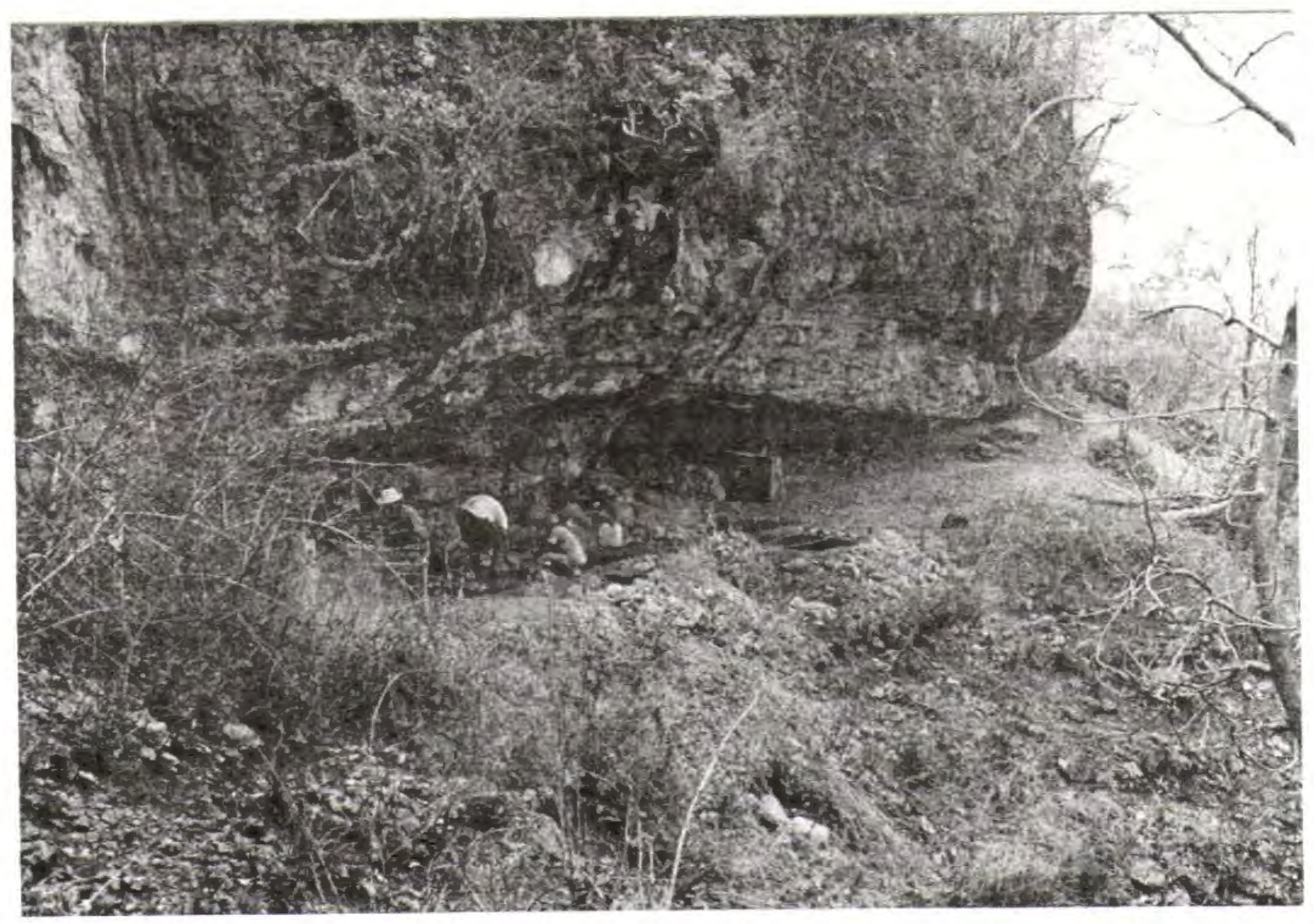


Pada dinding dan atap gua terlihat rekahan dan pori-pori dalam jumlah yang kecil. Hal ini disebabkan sinar matahari $80 \%$ dapat masuk ke dalam gua sehingga proses pelarutannya kecil, sedangkan proses pelapukan-nya cukup tinggi. Endapan tanah pada permukaan gua berwarna coklat terang, kelembaban kecil, kekompak-kan rendah, dengan ketebalan tanah sekitar $60 \mathrm{~cm}$. Di sekitar gua banyak terdapat batugamping kersikan rijang merah, kuning, coklat, dan hijau, kuarsa, kuarsit berukuran berangkal sampai bongkah, baik insitu maupun fragmental. Di depan gua mengalir Kali Areng yang terdapat singkapan intrusi andesit sebagai kontak antara satuan batuan batugamping kalkare-nit dengan batuan intrusi. Arah hadap gua ini ke
tenggara $\left(\mathrm{N} 125^{\circ}\right)$.

Berdasarkan hasil penelitian melalui ekavasi di Ceruk Layah manunjukkan adanya perbedaan yang menyolok antara temuan dari Gua Lawa (Heekeren, 1972) dengan temuan dari Ceruk Layah (Nurani, 2000;2001;2002). Perbedaan terletak pada variasi temuan, di mana temuan dari Gua Lawa memiliki temuan yang bervariasi baik artefak maupun ekofak bahkan rangka manusia, sedangkan temuan dari Ceruk Layah didominasi artefak litik (artefak batu). Kenyataan tersebut menimbulkan pertanyaan apakah terdapat pemanfaatan yang berbeda antara Gua Lawa dengan Ceruk Layah? Terlepas dari pertanyaan tersebut, berkaitan dengan tulisan ini, hal utama yang akan dikaji adalah perkembangan teknologi yang berlangsung berkaitan dengan mobilitas antara bahan baku (sumberdaya alam), artisan, dan aspek ekonomi. Untuk mengkaji hal tersebut, maka dalam tulisan ini digunakan pendekatan teknoekonomi.

Teknoekonomi terdiri dari kata "tekno" dan "ekonomi". Kata "tekno" mengacu pada perlengkapan teknis atau materiil dan pengetahuan yang ada dalam dan dapat dimanfaatkan oleh masyarakat. Sedangkan kata "ekonomi" menekankan pengaturan yang dilakukan oleh sesuatu masyarakat dalam menggunakan aturan perlengkapan teknis dan pengetahuan untuk produksi, distribusi, perlengkapan teknis dan pengetahuannya untuk produksi, distribusi, serta konsumsi barang dan jasa. Dalam pengertiannya yang dibatasi secara sewenang ini, teknologi adalah representasi cara pemberlakuan kesempatan itu dalam masyarakat. Dalam kebudayaan sistem teknoekonomi memiliki lima elemen pokok, yaitu cara perolehan makanan dan cara menghasilkan suatu barang untuk memenuhi kebutuhan (cara memproduksi), peralatan, tata cara pengadaan barang dan pekerjaan, peraturan untuk menata aktivitas ekonomi, dan pengetahuan yang membuat semua aktivitas itu dapat terlaksana (Gibbon, 1984).

Konsep tersebut menunjukkan adanya siklus yang saling terkait dan tidak terpisah antara sumberdaya alam, teknologi, dan penggunaan kekuatan fisik serta ide-ide untuk menghasilkan sesuatu dalam memenuhi kebutuhan material dan sosial. Suatu lingkungan alarn tertentu akan diikuti dengan pengembangan teknologi yang tertentu 
pula. Berkaitan dengan hal tersebut, tulisan ini mencoba menjelaskan dua hal sebagai berikut : bagaimana pengaruh potensi sumberdaya alam sekitar kawasan Sampung, Ponorogo dalam pengembangan teknologi industri litik dan bagaimana penataan aktivitas ekonomi berlangsung?

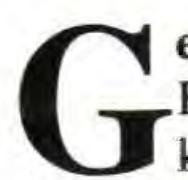

\section{eologis kawasan Sampung}

Kawasan Sampung, utamanya pada daerah perbukitan kapur memiliki kandungan gua atau ceruk sejumlah 16 buah. Secara geografis keletakan gua tersebut berada pada perbukitan kapur lereng tengah, di mana pada bagian lereng bawah terdapat Kali Areng. Gua/ceruk tersebut tidak seluruhnya memiliki indikasi hunian, hanya 6 buah gua yang memiliki indikasi hunian yaitu 5 buah gua (gua Lawa, gua Tutup, gua Padepokan, ceruk Layah, dan ceruk Ngalen) berada di bagian selatan, dan sebuah (gua Nggowos) berada di bagian utara perbukitan kapur Sampung. Indikasi hunian dida-sarkan pada hasil pengkaisan dan morfologi gua serta kondisi geografis sekitarnya.

Morfologi lahan Kecamatan Sampung terdiri atas 3 (tiga) bentuk lahan meliputi lahan dataran aluvial, perbukitan karst, dan dataran kaki gunung api (gunung Lawu). Dataran aluvial terletak pada bagian timur dan utara perbukitan karst yang dimanfaatkan sebagai areal permukiman dan persawahan. Bentuk lahan perbukitan karst merupakan areal perhutani dengan sebaran beberapa gua/ceruk. Areal perbukitan karst ini memanjang dari utara ke selatan, di mana pada bagian utara areal perbukitan sudah banyak yang ditambang. Sangat disayangkan, pada bagian ini terdapat sebuah gua (gua Ngowos) yang secara arkeologis sangat potensial, namun kondisinya sangat memprehatinkan (tingkat pengrusakan lanjut akibat penambangan sejak tahun 1923). Perbukitan karst ini terdiri atas lereng bawah yang merupakan Kali Areng, sedangkan lereng tengah dan lereng atas terdapat gua/ceruk. Sebagian besar gua/ceruk merupakan hasil rekahan dan pelarutan sehingga beberapa gua (gua Gedhe, gua Dlosor, Gua Nuton, dan gua Pertapan 2) terletak secara vertikal dan terjal pada punggung bukit. Keletakan gua tersebut secara eksisbilitas, menunjukkan tidak laiknya gua tersebut dihuni, selain sulit dijangkau, hasil pengkaisan juga tidak ditemukan indikasi hunian. Sedangkan bentuk lahan dataran kaki gunung api terletak pada bagian utara dari perbukitan kapur, saat ini areal tersebut dimanfaatkan sebagai persawahan dan perkebunan pinus.

Stratigrafi kawasan Sampung mengacu pada stratigrafi yang dikemukakan oleh Sampurno dan H. Samodra (1991), dapat diketahui urutan stratigrafi dari tua ke muda yaitu formasi Sampung, batuan terobosan, lahar Lawu tua, dan aluvial (lihat tabel di bawah ini). 


\section{Tabel Satuan Batuan Penyusun Daerah Sampung}

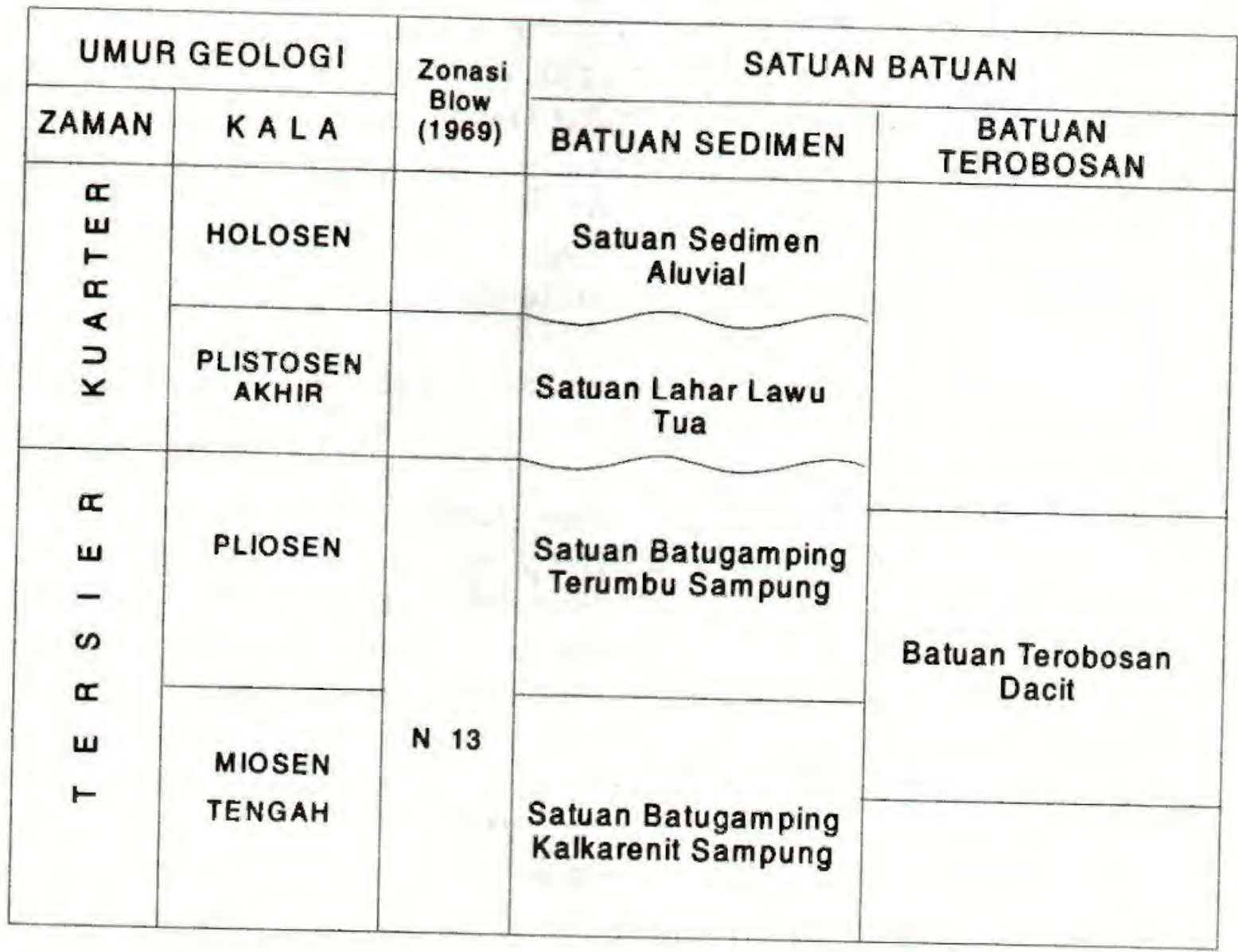

\section{Satuan batugamping kalkarenit formasi Sampung}

Berdasarkan pengamatan di lapangan, batugamping kalkarenit secara umum mempunyai ciri-ciri berwarna putih sampai putih kecoklatan, berukuran butir pasir halus sampai pasir kasar, derajat pemilahannya buruk dengan kemas yang terbuka dan memiliki porositas sedang. Semen pada satuan batuan ini merupakan semen karbonat yang banyak mengandung pecahan foram besar, cangkang moluska, koral, mineral kuarsa, piroksen, dan plagioklas. Kenampakannya terlihat jelas adanya perlapisan baik dengan ukuran ketebalan antara $20-400 \mathrm{~cm}$ dengan struktur sedimennya berupa perlapisan sejajar dan masif. Pada satuan batuan batugamping kalkarinit formasi Sampung terdapat sisipan napal. Napal ini memiliki ciri megaskopis yaitu berwarna putih kecoklatan, rapuh, mempunyai semen karbonatan, dan banyak mengandung fosil foram. Struktur sedimen yang berkembang pada batuan ini berupa perlapisan sejajar dengan ketebalan antara 15 sampai $80 \mathrm{~cm}$ dan kedudukan lapisan sekitar N90\%/E14.

Hasil analisis laboratorium mikropaleontologi bahwa satuan batuan batugamping kalkarinit mengandung fosil-fosil foram berupa Globoratalia siakensis, Globoratalia mayeri, Globigerina praebullides, Globigerinoides sacculifer, Globoratalia obesa, 
Globigerinoides subquadratus, Globorotalia menardii, dan Orbulina universa. Hal ini menunjukkan bahwa umur lapisan ini adalah Miosen Tengah (N13) dengan lingkungan pengendapan berada pada lingkungan neritik tengah. Di beberapa tempat memperlihatkan kekar-kekar tarik yang terisi oleh mineral hidrotermal berupa rijang merah, rijang coklat, rijang hijau, dan rijang kuning. Hal ini disebabkan oleh adanya batuan terobosan yang membawa larutan hidrotermal tersebut, bahkan mineral kuarsa pun tersingkap walaupun dalam jumlah yang sangat sedikit.

\section{Satuan batuan batugamping terumbu formasi Sampung}

Setelah pengendapan satuan batuan batugamping kalkarinit, secara sejajar di atasnya terjadi pula pembentukan satuan batuan batugamping terumbu. Satuan Batuan Batugamping terumbu secara megaskopis mempunyai ciri-ciri berwarna putih kecoklatan - abu-abu kecoklatan, semen karbonatan, kekompakan baik, dan mengandung fosil-fosil foram. Kandungan fosil foram didominasi oleh cangkang moluska baik cetakan luar maupun cetakan dalam dari foram moluska. Selain itu adanya kandungan koral terutama ganggang merah Corallinae merupakan bahan dasar warna dari batuan hidrotermal berupa rijang merah, rijang coklat, rijang hijau, dan rijang kuning yang banyak terdapat pada satuan batuan batugamping terumbu formasi Sampung. Satuan batuan ini memperlihatkan struktur lapies dan membentuk perbukitan karst kerucut dengan ketinggian 10-40 m sedangkan untuk pengumuran yang berdasarkan korelasi stratigrafi vertikal menunjukkan Pleo-Plistosen dengan lingkungan pengendapan berupa neritik tepi dengan gelombang air yang tenang. Di beberapa tempat juga memperlihatkan kekar-kekar tarik yang terisi oleh mineral hidrotermal berupa rijang merah, rijang coklat, rijang hijau, dan rijang kuning. Banyak tersingkap pada permukaan yaitu pada bentukan-bentukan lapies.

\section{Satuan batuan terobosan}

Akibat terjadinya geotektonik pada lempeng samudra maka terjadi pula terobosan magma pada zona-zona lemah. Tak terkecuali di daerah Sampung mengalami hal yang sama yaitu terdapatnya batuan terobosan berupa batuan beku dengan ciri-ciri berwarna abu-abu terang memiliki kekompakan baik, dan berfanerik kasar. Selain itu batuan ini berderajat kristal yang holokristalin dengan derajat pembundaran subhedral, sedangkan komposisi mineral yang terkandung terdiri dari piroksen, hornblende, plagioklas, dan kuarsa. Bentuk terobosan yang tampak di la[pangan berupa stock yaitu memperlihatkan kemiringan dinding terobosan sekitar $80-85^{\circ}$ dan penyebarannyapun setempat-setempat. Singkapan batuan ini yang sangat jelas terdapat pada sungai Areng dan gunung Leng. Adanya xenolit Basalt di Gunung Leng dan xenolit batugamping menunjukkan bahwa batuan ini terbentuk setelah satuan batuan batugamping Formasi Sampung terbentuk atau dengan kata lain pembentukannya berumur Miosen Akhir (Pleo-Plistosen). 


\section{Endapan lahar Lawu tua}

Endapan lahar Lawu tua merupakan batuan breksi polimiks yang memiliki ciri-ciri sebagai berikut warna putih kecoklatan - abu-abu kehitaman, fragmen terdiri dari andesit, basalt, dan batupasir yang mengambang pada masa dasar material berukuran pasir dan batu tuffan. Ukuran butir dari satuan batuan ini berukuran pasir kasar bongkah yang berbentuk menyudut tanggung - membulat tanggung, sedangkan kemasnya merupakan kemas terbuka sehingga pemilahan buruk dan porositasnya sedang. Untuk pengumurannya oleh van Bemmelen (1949) dikatakan bahwa kegiatan Gunung Api Lawu dimulai sejak Plistosen Tengah dan mencapai puncaknya pada Plistosen Akhir dan pengendapannya pada lingkungan darat.

\section{Aluvial}

Aluvial tersusun oleh material rombakan dari batuan yang lebih tua dan berada disekitarnya. Material ini terdiri dari material lepas berukuran butir lempung hingga bongkah yaitu berupa andesit, basalt, batupasir, batugamping, rijang, andesit, dan batulanau. Sesuai dengan tempat diendapkannya, aluvial diendapkan pada lingkungan darat berumur kala Holosen sampai sekarang.

H asil ekskavasi Ceruk Layah

Ekskavasi yang dilakukan di Ceruk Layah menggunakan sistem grid di mana bagian lebar (transversal) dengan huruf, sementara pada bagian panjang
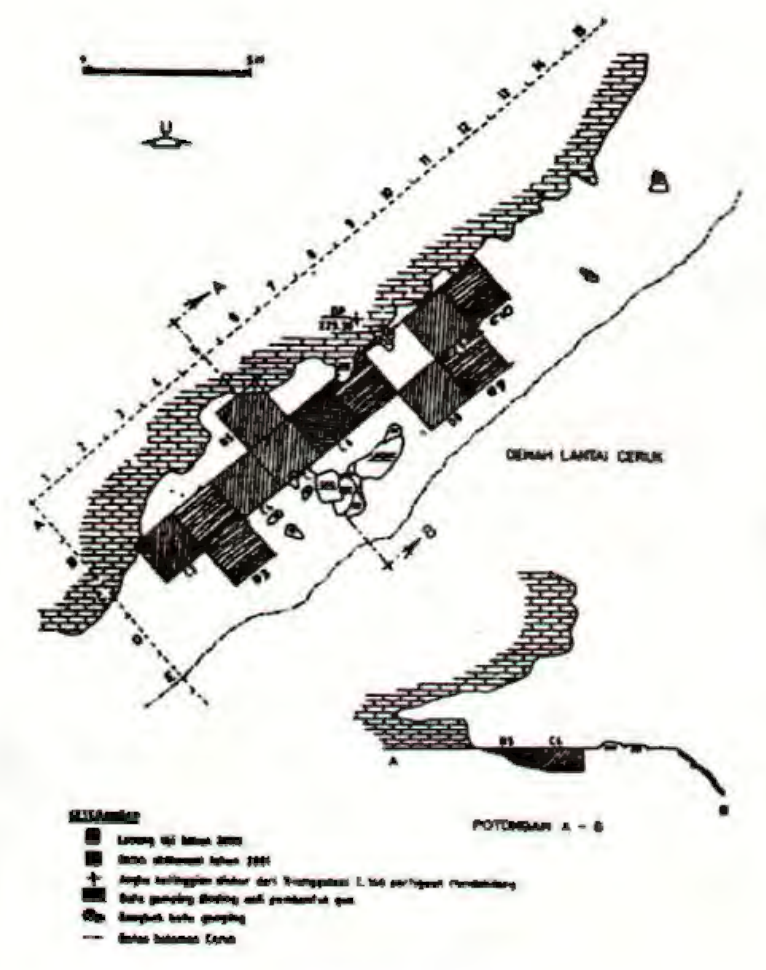
(longitudinal) dengan angka sehingga terdapat kotak dengan nama A-1, B-1, C-3, dst.

Berdasarkan posisi lahan ceruk yang sempit dan tidak berorientasi ke arah utara selatan, maka dibuat grid dengan orientasi $\mathrm{N} 51^{\circ}$. Ekskavasi yang dibuka meliputi 12 (dua belas) kotak yaitu B-5, C-2, C-4, C-5, C-6, C-9, D-8, C-3, C-7, C-10, D-3, dan D9. Hasil ekskavasi menunjukkan adanya 4 (empat) lapisan tanah, di mana pada lapisan ke empat merupakan lapisan bedrock berupa formasi Sampung. Ke empat lapisan tanah ini dapat diuraikan sebagai berikut (Nurani, 2002). 
Lapisan 1 merupakan top soil, warna coklat gelap, ukuran butir pasir halus, kekompakan kecil, kelembaban kecil, fragmen batuangamping berukuran kerikil, arang kayu berukuran $2-3 \mathrm{~mm}$, banyak terdapat akar halus dari tumbuhan, strukturnya masif, tekstur kasar. Temuan pada lapisan ini meliputi fragmen tembikar, fragmen tulang fragmen cangkang siput, dan artefak litik.

Lapisan 2 merupakan pasir lempungan, coklat keabu-abuan, berukuran butir pasir sangat halus, kekompakan sedang, kelembaban kecil, semen karbonatan, fragmen batugamping berukuran kerakal - kerikil, sebaran tembikar, sedikit arang kayu berukuran 5-10 mm., struktur masif, tekstur halus, pemilahan sedang. Temuan lapisan ini : fragmen tembikar, fragmen tulang, fragmen cangkang siput, dan artefak litik.

Lapisan 3 merupakan endapan lempung pasiran, coklat terang, kekompakan sedang, kelembaban kecil, semen karbonatan, fragmen batugamping berukuran berangkal kerakal, struktur masif, tekstur kasar, pemilahan buruk. Temuan pada lapisan ini adalah artefak batu baik berupa alat serpih maupun serpihan alat.

Lapisan 4 merupakan lapisan bedrock satuan batuan batugamping Formasi Sampung.

Keseluruhan temuan hasil ekskavasi dapat dilihat pada grafik berikut.

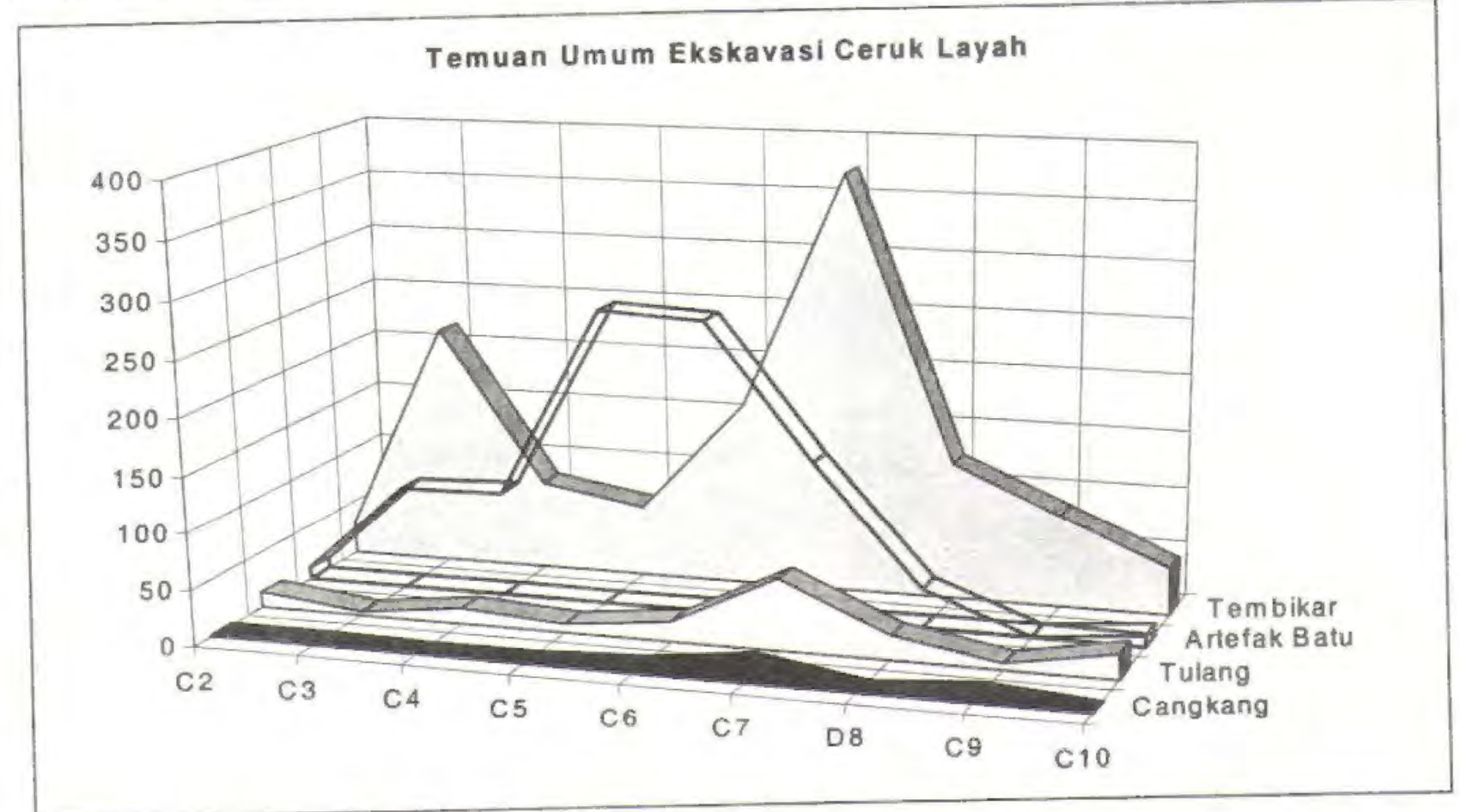

Grafik di atas menunjukkan temuan terbanyak adalah tembikar disusul artefak batu. Kedua temuan tersebut menempati lokasi yang berbeda, tembikar cenderung menempati bagian kanan dan kiri lahan gua, sedangkan artefak litik menempati lahan bagian tengah. 


\section{Kuantitatif artefak litik}

Temuan artefak litik dalam hal ini merupakan alat dan non alat. Untuk temuan non alat berupa serpihan batu sebagian besar merupakan bahan dasar dari berbagai jenis batuan, selain beberapa merupakan limbah (debris) dari pembuatan alat, dan batu inti. Secara kuantitatif temuan artefak batu dapat dilihat pada grafik berikut.

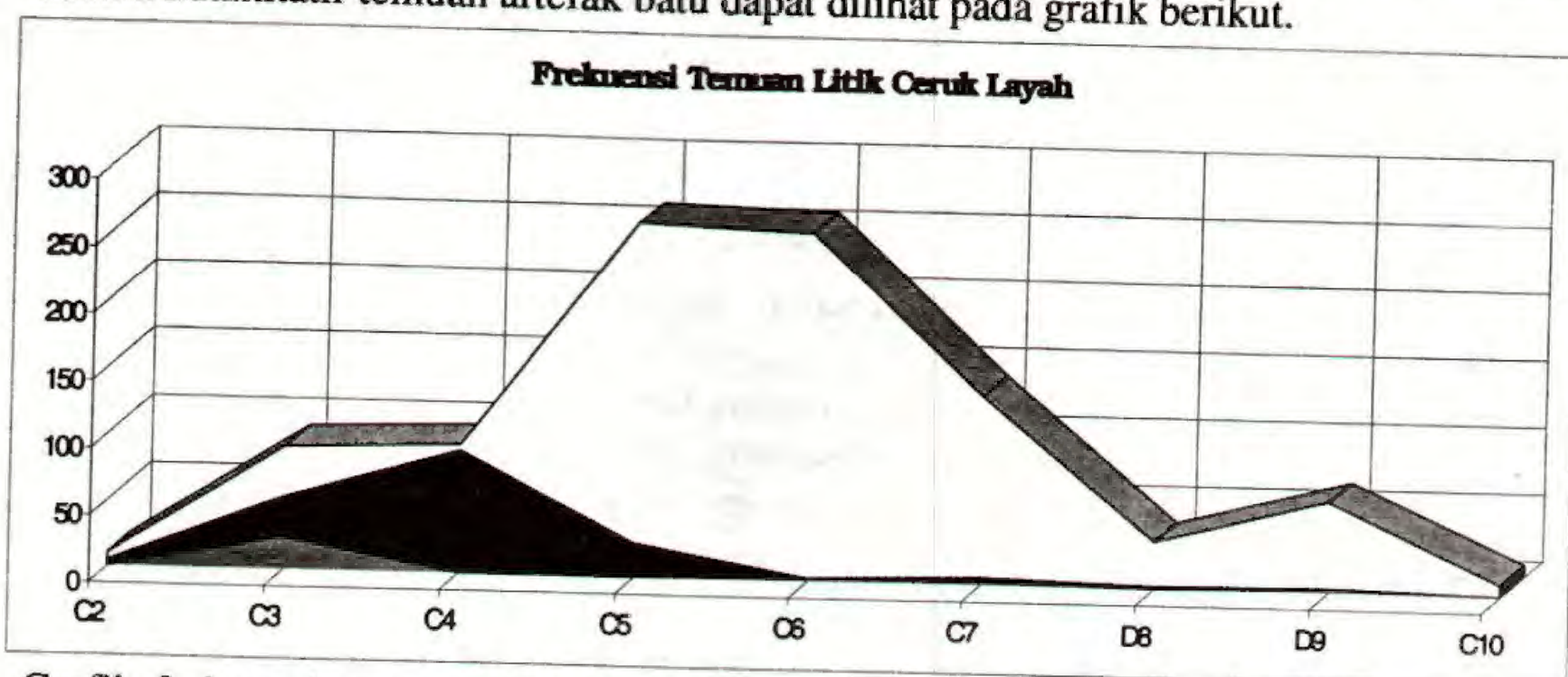

Grafik frekuensi temuan litik di atas menunjukkan temuan terbanyak terletak pada bagian tengah yaitu kotak C5, C6, dan C7. Semakin ke kiri dan ke kanan temuan litik semakin menurun. Kotak-kotak pada grafik di atas diambil pada posisi longitudinal. Selanjutnya untuk mengetahui frekuensi vertikal (waktu) per lapisan temuan litik, dapat dilihat grafik berikut.

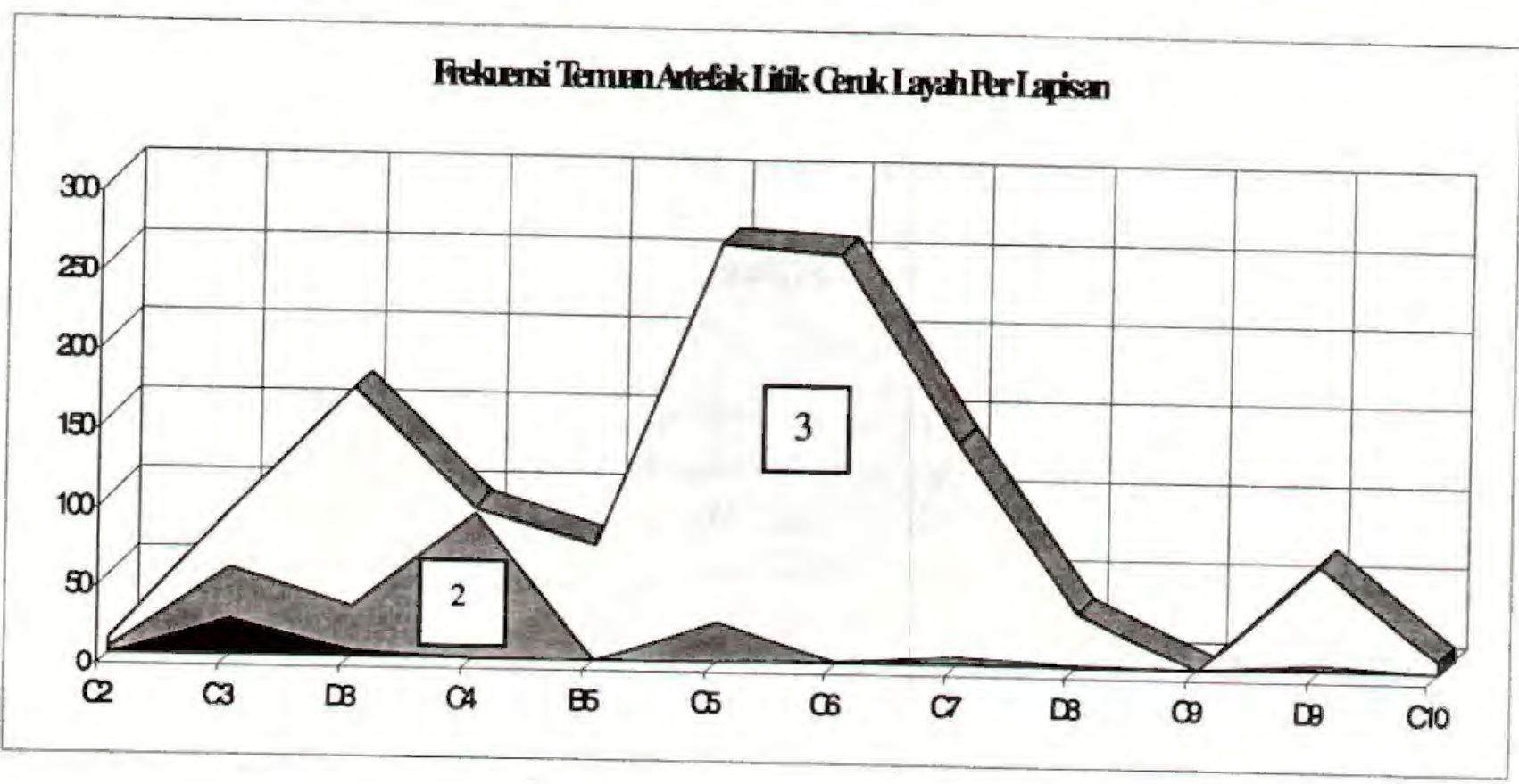


Pada grafik per lapisan temuan litik ini menunjukkan adanya frekuensi yang signifikan. Lapisan pertama temuan litik sangat minim, hanya ditemukan pada kotak C3, selanjutnya pada lapisan kedua temuan litik mulai banyak meskipun belum merata pada semua kotak. Sedangkan pada lapisan ketiga temuan litik sangat banyak dan hampir merata pada seluruh kotak gali. Pada lapisan ketiga ini temuan litik sudah menghilang pada kotak C4. Kotak C4 menunjukkan temuan artefak litik hanya ditemukan pada lapisan kedua saja. Sedangkan satu-satunya kotak yang tidak ditemukan artefak litik adalah kotak $\mathrm{C}$.

\section{Kualitatif artefak litik}

\section{a. Bahan dasar alat (raw - materials)}

Keberadaan bahan baku seperti rijang (chert) berwarna merah, coklat, kuning, dan hijau kemudian meta gamping (silicified limestone), dan andesit (andesite) dapat dijumpai dalam radius $1 \mathrm{~km}^{2}$, sedang bahan baku silisifikasi tufa (silicified tuff), kalsedon (calsedone) ataupun kwarsa (quarst) kemungkinan dapat ditemui dalam radius lebih dari $1 \mathrm{~km}^{2} \mathrm{ke}$ arah utara. Hal ini dapat diungkapkan karena proses pengendapan dan hidrotermal sangat dominan di wilayah utara dibanding wilayah selatannya (periksa bab B $\rightarrow$ geologis Sampung). Himpunan batu rijang merah, coklat, dan kuning serta andesit cukup tersebar dan dapat dijumpai pada aliran Kali Areng yang mengalir membelah bukit-bukit yang ada di gugusan Gunung Angel. Keberadaan rijang hijau maupun meta gamping dapat dijumpai pada teras-teras di dataran rendah atau perbukitan yang ada di sekitarnya. Bahan baku tersebut muncul sebagai proses hidrotermal yang mengintrusi titik-titik terbuka pada blok-blok atau bongkahan batuan andesit yang ada di teras Kali Areng. Proses hidrotermal tersebut mempengaruhi kualitas batu. Bongkahan bahan baku yang terletak di sekitar Kali Areng merniliki kualitas rendah dengan pori-pori besar sehingga mudah rapuh. Sementara bahan baku yang terletak semakin tinggi di lereng perbukitan kapur berkualitas baik dengan tingkat silikaan tinggi. Sedangkan pada puncak bukit bahan baku tersebut tidak ada.

Kaitannya dengan industri litik pendukung situs Ceruk Layah terdapat dua faktor yang sangat mempengaruhi pola pikir mereka dalam mengeksploitasi bahan baku sebagai bahan utama dalam membuat artefak litik. Pertama adalah faktor ekonomis. Faktor in. cukup menentukan karena mereka tidak cukup banyak membuang waktu dan tenaga serta jarak jangkau mereka untuk memperoleh bahan baku baik dalam bentuk blok/bongkahan berukuran relatif kecil atau sedang. Mereka memangkas pada blok/bongkahan yang ada, atau membawanya ke lokasi hunian untuk kemudial diserpih menjadi bentuk-bentuk artefak. Efisiensi ini membawa mereka pada suatu pola kerja yang cenderung hanya tergantung pada sumberdaya alam sekitarnya dan juga terhadap proses kehidupan yang praktis. Kedua adalah faktor oportunis, yaitu 
tidak adanya usaha untuk mendapatkan hasil yang diinginkan dalam membuat suatu bentuk peralatan kerja atau yang khas bagi mereka, tetapi hanya ingin mendapatkan sebanyak mungkin serpih dan serpihan litik yang selanjutnya digunakan seperlunya, sedang selebihnya dibiarkan begitu saja atau akan dipergunakan pada waktu yang tidak ditentukan yang disesuaikan dengan kondisi alam saat itu. Kedua faktor ini tentu juga menghasilkan hal-hal yang menguntungkan ataupun merugikan. Keuntungan dari proses faktor pertama adalah mereka tidak perlu membuang waktu meninggalkan aktivitas sehari-hari serta hanya memerlukan jarak yang tidak cukup jauh untuk mendapatkan bahan baku artefak litik, sedang ruginya cenderung pada ketergantungan terhadap bahan baku yang notabene tidak mempunyai kualitas baik menjadikan artefak-artefak tersebut ke bentuk dan tipe peralatan yang tidak berkembang. Keuntungan dari proses faktor kedua adalah mereka cukup banyak mempunyai persediaan bahan atau artefak (serpih dan serpihan) dalam membuat alat, karena cukup banyak yang telah mereka hasilkan dalam tahapan pemangkasan dan penyerpihan sebelumnya. Untuk ruginya adalah tidak adanya kualitas batuan yang baik dan umumnya berupa artefak-artefak kecil (microlit) dan tidak beraturan yang dominan oleh artefak kortikal (cortical flakes).

\section{b. Alat Serpih}

Alat serpih (flake) terdiri atas dua tipe yaitu serpih tanpa retus dan serpih dengan retus pemakaian. Serpih tanpa retus pada umumnya memiliki ciri-ciri teknologis yang lengkap sebagai hasil pengerjaan manusia, yaitu hadirnya dataran pukul, bulbus, dan terkadang luka pukul. Bentuknya bervariasi sebagaimana juga ukurannya. Sedangkan serpih dengan retus memiliki ciri-ciri teknologis, morfologis, dan metrik yang sama dengan serpih tanpa retus. Perbedaannya hanya terletak pada kehadiran retus di bagian tertentu dari sisinya, retus-retus tersebut merupakan bekas-bekas pengerjaan penyempurnaan agar sisi tersebut lebih "efficace" dalam pemakaiannya. Selain itu serpih dengan retus cenderung dibentuk segitiga secara sengaja selanjutnya dibuat retus baik secara bergerigi maupun dalam ukuran mikro atau cekung pada bagian lateral.

Temuan alat serpih dari hasil ekskavasi sebagian besar merupakan serpih yang dipersiapkan yaitu dengan membuat pangkasan-pangkasan pada bagian dorsal dan selanjutnya dilepaskan dari batu inti secara tidak langsung dengan menggunakan perkutor secara keras. Pangkasan pada bagian dorsal antara 3--6 yang dilakukan secara longitudinal dan beberapa dilakukan secara sentripetal. Hal yang menjadi kekhasan alat serpih pada Ceruk Layah ini adalah berpunggung tinggi dan tebal.

Beberapa alat serpih yang sengaja dibentuk segitiga dengan pembuatan retus secara efektif pada bagian lateral terutama tampak pada temuan kotak C-5 pada kedalaman antara 28 s.d. $45 \mathrm{~cm}$ dari permukaan tanah sejumlah 11 buah. Serpih dipersiapkan dengan bagian dorsal dipangkas secara longitudinal menyudut (berpunggung tinggi). 
Bagian ventral dibiarkan polos. Setelah lepas dari batu inti dibuat retus gigir secara intensif pada bagian lateral baik kanan maupun kiri. Peretusan tampak adanya kesengajaan dibuat struktur segitiga meruncing. Ukuran serpih ini adalah 4,2 x 3,2 x $1 \mathrm{~cm}$.

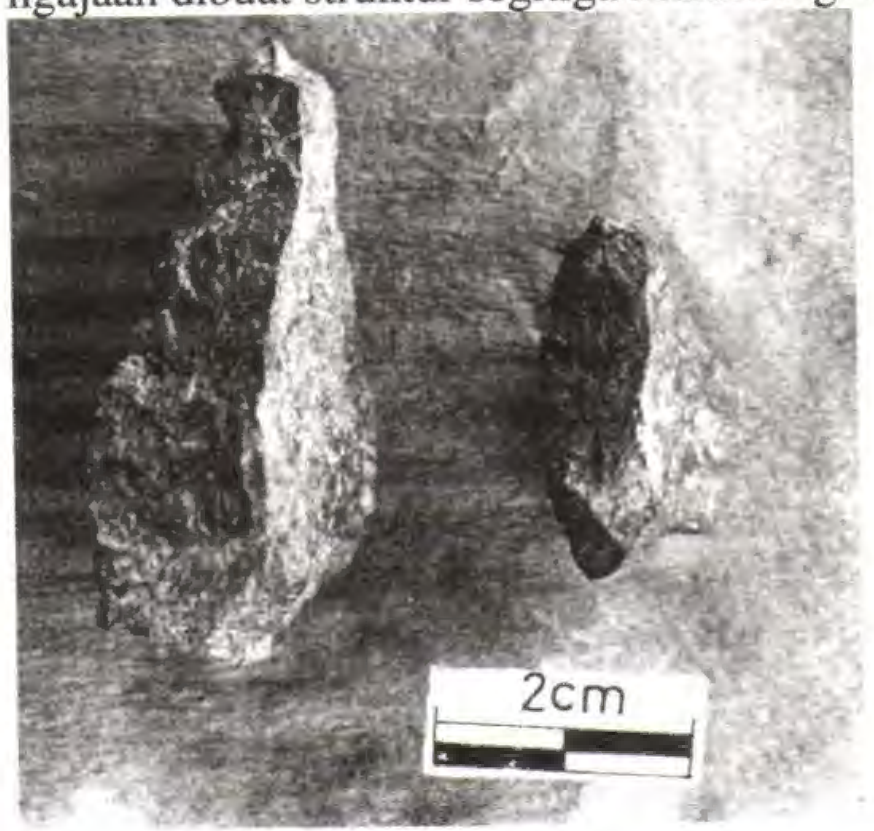

Kemungkinan serpih ini merupakan mata panah berdasar cembung. Temuan serupa yang ditemukan pada kedalaman yang sama adalah berupa serpih yang dipersiapkan dengan membuat pangkasan-pangkasan pada bagian dorsal, pangkasan longitudinal yang diikuti dengan pangkasan secara transversal, sehingga tampak seperti bentuk daun. Terdapat jejak-jejak pemakaian secara intensif pada bagian lateral kanan. Bagian lateral menipis sementara puncak dorsal berpunggung tinggi.

Bentuk segitiga pada sebagian besar alat serpih ini tampaknya cenderung akan dibuat matapanah, namun belum sempurna. Beberapa spesimen masih tampak adanya dataran pukul yang tebal, namun dari segi pembuatan retus tampak intensif dengan membentuk retus mikro dan bergigir pada bagian lateral baik kiri maupun lateral kanan. Selain itu bekas-bekas pemakaian (perimping) juga menun-jukkan tingkat intensif yang tinggi.

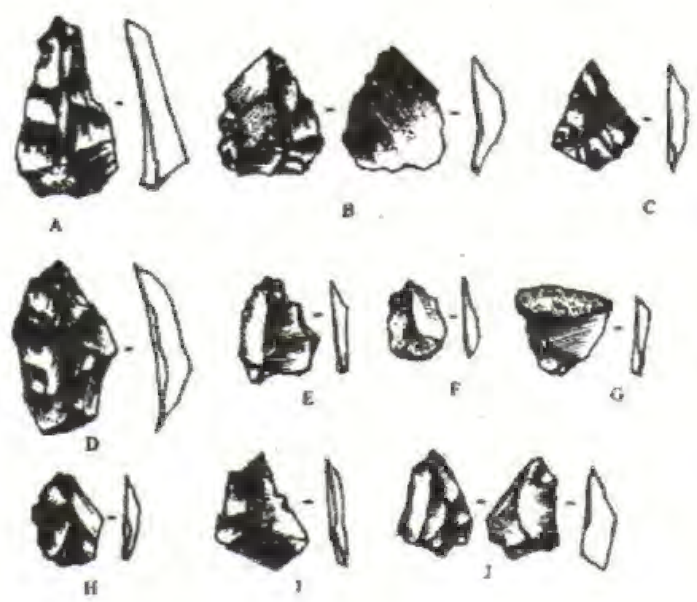

Temuan alat serpih berbentuk segitiga juga ditemukan pada kotak B-5 kedalaman antara $30-70 \mathrm{~cm}$ (interval besar ini terjadi disebabkan 3/4 kotak sudah tertutup lapisan batugamping formasi Sampung). Spesimen ini dari bahan kalsedon merah menunjukkan bagian ventral dibiarkan polos, sementara bagian dorsal dipangkas secara longitudinal yang dilanjutkan pangkasan secara transversal (menyerupai daun). Pada bagian lateral dibuat retus ukuran mikro secara bergigir, sedangkan bagian proksimal tanpa retus dan berukuran lebar yang lebih pendek (sebagai tangkai). Ukuran serpih ini adalah $2,4 \times 1,5 \times 0,7 \mathrm{~cm}$. Temuan lain pada kedalaman yang sama adalah dengan dipangkas sangat tipis dari bahan kalsedon kuning. Bagian ventral dibiarkan polos, bagian dorsal dipangkas sejumlah 6 pangkasan, sementara pada bagian lateral dibuat retus cekungan kecil. Dataran pukul sudah tidak tampak. Ukuran 
serpih ini adalah $2,2 \times 2,1 \times 0,3 \mathrm{~cm}$. Temuan serupa juga ditemukan pada kotak C-2 kedalaman 37 - $61 \mathrm{~cm}$ dari permukaan tanah, ukuran serpih ini adalah 1,6 x 1,6 x 0,4 $\mathrm{cm}$ dari bahan rijang abu-abu.

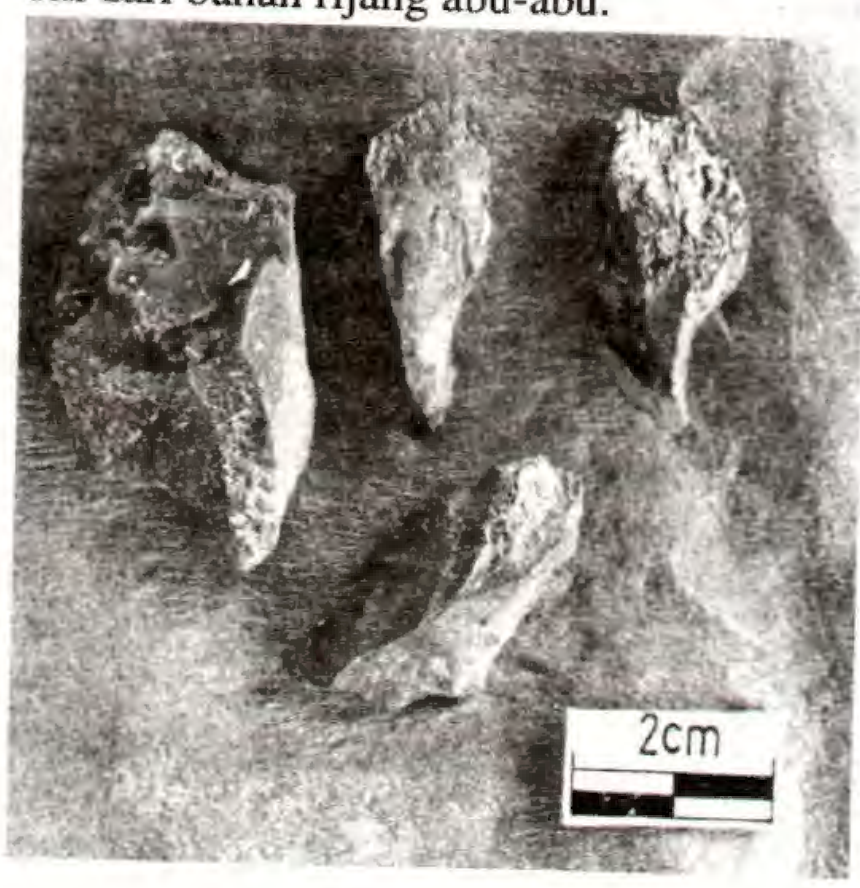

Temuan alat serpih selain berbentuk segitiga sebagaimana telah diuraikan di atas, terdapat pula tipe yang menarik yaitu tipe bor. Bor merupakan alat dimana pada bagian tertentu (umumnya di bagian distal) terdapat bagian meruncing yang dibentuk secara sengaja. Pada umumnya bentuk dasar runcingan telah tercipta pada serpih, melalui persiapan-persiapan awal sebelum pemisahan dari batu inti. Bentuk dasar ini kemudian disempurnakan melalui peretusan sisi atau pembuatan cekungan pada kedua sisi runcingan. Letak runcingan dapat melahirkan beberapa bentuk bor, adakalanya terletak pada salah satu sudut dengan arah runcingan menyilang terhadap sumbu morfologi alat.

Selain itu letak runcingan ada juga di bagian tengah sisi distal bertumpu pada sumbusumbu morfologi alat. Sering pula runcingan dibuat dengan mengerjakan salah satu sisi lebih intensif dari sisi lain sehingga melahirkan bentuk khas melengkung. Bor ditemukan pada kotak C-5 kedalaman $28-45 \mathrm{~cm}$ dari permukaan tanah, yang dicirikan oleh runcingan yang berbentuk miring melengkung menyerupai paruh burung. Dalam pembentukan runcingan tampak adanya kesengajaan. Sedangkan pada bagian lateral kiri dan kanan terdapat retus yang dibuat secara mikro dan cekungan kecil. Berdasarkan pengamatan, tampaknya alat ini dilakukan secara intensif baik pada bagian distal, proksimal, maupun lateral. Ukuran bor ini adalah $3,1 \times 1,5 \times 0,7 \mathrm{~cm}$. Temuan lain adalah dari kotak C-4 kedalaman $10-40 \mathrm{~cm}$ yaitu pada bagian dorsal dipangkas secara longitudinal, selanjutnya setelah terlepas dari batu inti dibuat tajaman melengkung secara sengaja, sementara bagian distal dibuat retus mikro secara bergigir. Spesimen ini menunjukkan hanya pada salah satu lateral saja yang dibuat retus bergigir secara intensif. Ukuran bor ini adalah $2,5 \times 1,3 \times 0,6 \mathrm{~cm}$.

\section{c. Bilah}

Bilah (blade) secara teknologis sama dengan serpih, perbedaan yang mendasar antara alat serpih dengan bilah adalah pada bentuk alat atau dari aspek morfologisnya saja. Alat serpih berbentuk pipih melebar, sedangkan bilah berbentuk memanjang dengan ukuran panjang minimal 2 kali ukuran lebarnya. Kedua sisi panjang umumnya 
bertemu di ujung dan membentuk lancipan. Bagian ventral dibiarkan polos tanpa faset namun ada juga yang dipangkas lagi dengan satu pangkasan memanjang untuk penipisan. Sedangkan bagian dorsal biasanya dipangkas melalui faset-faset penyerpihan yang sudah dipersiapkan. Pada bagian dorsal umumnya didominasi oleh pangkasan memanjang yang membentuk punggung alat dengan penampang irisan transversal berbentuk segitiga.

Temuan bilah ditemukan pada kotak C-4 kedalaman 10 - $40 \mathrm{~cm}$ sejumlah 3 buah. Hal yang tampak jelas adalah adanya kesengajaan serpih yang dibuat secara memanjang, 3 pangkasan secara longitudinal dibentuk pada bagian dorsal, sementara bagian ventral dibiarkan polos. Pada bagian lateral dibuat retus mikro. Ukuran bilah ini adalah $3,7 \times 1,6$ x $0,8 \mathrm{~cm}$.

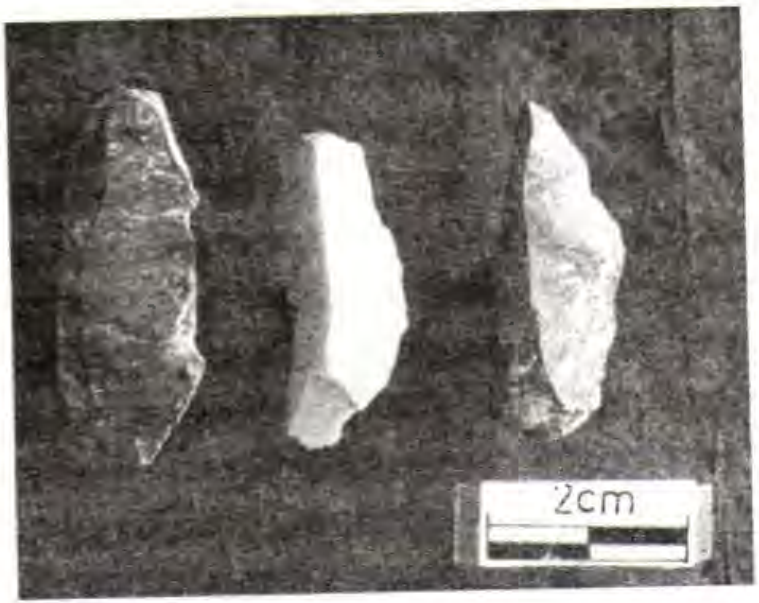

Spesimen lainnya adalah dengan dibuatnya retus cekungan dan mikro pada bagian distal, sementara bagian proksimal yang tebal tanpa retus. Ukuran bilah ini adalah 2,9 x $1,9 \times 0,9 \mathrm{~cm}$. Temuan lain adalah dari kotak B-5 kedalaman $30-70 \mathrm{~cm}$ dari permukaan tanah dua buah. Kedua temuan ini dengan khas berpunggung tinggi beretus pada satu lateralnya saja. Ukuran bilah adalah $3,3 \times 1,8 \times 1,3 \mathrm{~cm}$ dan $3,4 \times 1,6$ x $1 \mathrm{~cm}$. Selain itu dari kotak D-8 hanya ditemukan sebuah pada kedalaman antara 52 $87 \mathrm{~cm}$ dari permukaan tanah, dengan ukuran $3,4 \times 1,3 \times 0,9 \mathrm{~cm}$.

\section{d. Serut}

Serut (scraper) adalah alat yang telah dipakai, yang tidak menunjukkan ciri teknologis seperti yang ditunjukkan oleh alat serpih dan bilah. Unsur pemakaian dan ukuran alat yang tergolong alat nonmasif merupakan kriteria terpenting untuk kategori alat ini. Tidak ada pembentukan melalui pemangkasan ataupun penyerpihan untuk memperoleh bagian tajamannya. Oleh karena itu, serut dapat berupa serpihan-serpihan batu ataupun sekedar batu alam yang kemudian dipakai. Tidak adanya kriteria yang mendasar untuk masalah teknologis ini menyebabkan kemungkinan bergantinya kategori serut apabila dihadapkan pada ukuran alat besar (alat masif) yang dikategorikan sebagai kapak perimbas. Berdasarkan pada kriteria unsur pemakaian inilah, maka dalam tipe alat serut muncul tipe-tipe lain yang ditunjukkan pada keletakan retus atau unsur pemakaian. Adapun tipe-tipe serut meliputi serut ujung, samping, bergigir, cekung, cembung, dan sebagainya.

Serut samping (side scraper) dicirikan oleh keberadaan retus yang teratur menutupi sebagian besar atau seluruh sisi alat. Beberapa alat tipe ini terdapat pengerjaan retus 
secara intensif sampai menutupi sebagian alat, bahkan seluruh keliling alat. Tipe ini ditemukan pada temuan nomor 2 dari kotak C-4, sebagaimana telah dijelaskan di atas temuan ini juga berpunggung tinggi. Temuan serut lainnya adalah serut cekung (notch) dicirikan oleh keberadaan satu atau dua cekungan dan banyak cekungan yang dibentuk tidak bersambung. Cekungan dapat berupa "mikro retus" (retus cenderung kecil dan terbatas pada tepian alat) atau "clactonian" (cekungan besar melalui peretusan tunggal). Kedua cekungan tersebut merupakan aspek teknis yang tidak berkaitan dengan aspek pemakaian.

Tipe ini ditemukan pada kotak C-4 kedalaman $40-81 \mathrm{~cm}$ dari permukaan tanah. Untuk pembuatan cekungan pada serut ini melalui satu pangkasan, selanjutnya dibentuk retus mikro. Selain itu pada bagian ujung (distal) dibuat retus secara intensif. Kemungkinan selain difungsikan sebagai serut juga digunakan sebagai bor melihat runcingnya bagian distal yang dilanjutkan pembuatan retus sekelilingnya. Selain itu pada kedalaman antara 10 - 40 pada kotak C-4 ini juga ditemukan sebuah serut cekung. Cekungan tampak sengaja dibuat, selanjutnya dibuat retus cekungan, pada bagian lateral dibuat retus mikro. Ukuran serut ini adalah $2,5 \times 1,7 \times 0,7 \mathrm{~cm}$ dari bahan rijang hijau.

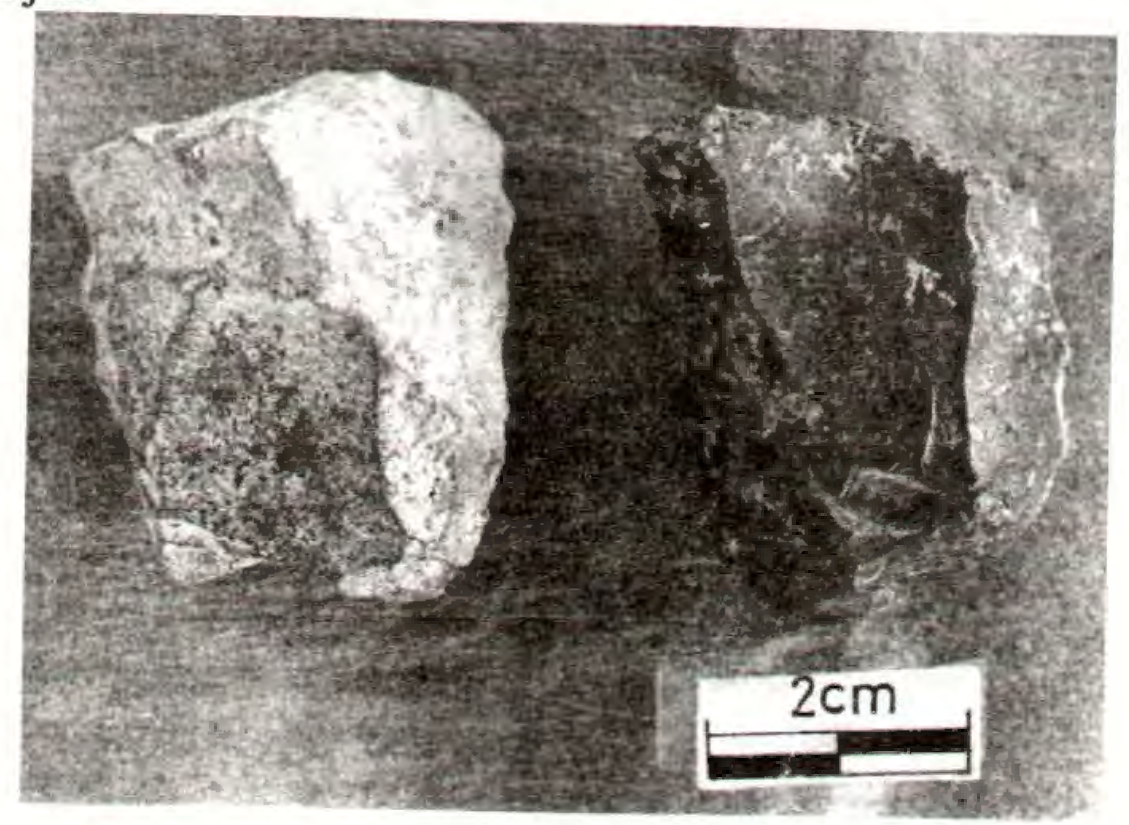

\section{Deknoekonomi produk industri litik dalam aktivitas komunitas gua
di Sampung}

Produk industri litik sebagaimana diuraikan pada bagian sebelum ini baik dari segi sumberdaya alam maupun teknologi dan tipologi yang diterapkan, menunjukkan adanya dua faktor yang menentukan yaitu faktor ekonomi dan faktor oportunis. Selanjutnya, untuk mengetahui keterkaitan antara Ceruk Layah yang didominasi temuan alat litik dengan Gua Lawa yang memiliki temuan bervariasi, berikut akan diuraikan bagaimana hubungan aktivitas antargua dalam aktivitas komunitasnya erlangsung. 
Sebagaimana telah diketahui, penghuni gua masa prasejarah dalam mempertahankan hidupnya sangat dipengaruhi ketersediaan sumberdaya alamnya baik sebagai sumber makanan maupun bahan baku untuk pembuatan peralatan. Sumberdaya alam Sampung, sebagaimana telah diuraikan pada awal tulisan ini merupakan bentuk lahan yang bervariasi (perbukitan karst, aluvial, dan dataran gunung api) di mana masingmasing lahan tersebut ketersediaan makanan (flora dan fauna aquatik dan non aquatik) dan bahan baku untuk pembuatan alat mencukupi. Selanjutnya telah diuraikan pada bab B tentang geologis kawasan Sampung menunjukkan bahwa bahan baku batu memiliki kualitas yang berbeda antara bagian bawah sekitar Kali Areng di mana Gua Lawa berada, dengan lereng-lereng perbukitan kapur (letak Ceruk Layah). Kualitas bahan baku dan keletakan gua/ceruk, menunjukkan adanya pola tersendiri berkaitan dengan pemanfaatan lahan gua/ceruk pada kawasan ini. Gua Lawa yang memiliki temuan bervariasi menunjukkan aktivitas multi fungsi, sedangkan Ceruk Layah yang didominasi temuan artefak litik menunjukkan aktivitas tunggal yaitu sebagai tempat untuk pembuatan alat litik.

Aktivitas multi fungsi Gua Lawa meliputi aktivitas pengolahan makan (dapur) yang dibuktikan dengan temuan ekofak (sisa makanan berupa fragmen tulang dan cangkang moluska), aktivitas pembuatan alat (bengkel) dengan bukti temuan artefak baik alat, limbah, maupun bahan baku, dan kubur (temuan rangka manusia). Sedangkan aktivitas tunggal di Ceruk Layah dibuktikan dengan temuan yang didominasi artefak litik baik temuan berupa limbah, produk alat, maupun bahan baku serta batu inti. Perbedaan aktivitas dan di lain pihak kualitas bahan baku di mana semakin tinggi lahan memiliki kualitas baik, menuntut mereka melakukan pengaturan pemanfaatan lahan gua dalam beradaptasi dengan lingkungan alam sekitarnya. Gua Lawa yang memiliki lahan luas dan terletak dekat sungai dimanfaatkan sebagai tempat untuk aktivitas mulit fungsi, sedangkan Ceruk Layah di mana daerah sekitarnya merupakan sumber bahan baku dimanfaatkan sebagai tempat pembuatan alat litik. Berdasarkan perbedaan aktivitas dan kualitas bahan baku tersebut dalam menyiasati dan beradaptasi lingkungan alam sekitarnya, menunjukkan adanya karakter tersendiri dalam pola permukiman yang berlangsung di kawasan ini. Selanjutnya berdasarkan pengamatan teknologi dan tipologi dari Ceruk Layah, menunjukkan bahwa manusia saat itu mengeksploiter alam secara maksimal. Efektivitas energi dan teknologi dalam menghasilkan alat litik tampak tinggi, meskipun secara tipologis cenderung rendah. 
$\mathbf{P}$ enutup

Berdasarkan penjelasan dan uraian di atas, dapat disimpulkan hal-hal sebagai

1. Aspek teknoekonomi dalam pembuatan alat litik temuan dari Ceruk Layah menunjukkan adanya dua faktor yaitu faktor ekonomi dan oportunis.

2. Kualitas bahan baku batu untuk pembuatan alat litik berbeda antara daerah sekitar Kali Areng dengan lereng-lereng perbukitan kapur. Bahan baku batu daerah Kali Areng memiliki kualitas rendah, semakin tinggi ke lereng-lereng perbukitan kapur, bahan baku batu semakin tinggi kualitasnya.

3. Teknologi alat litik Ceruk Layah menunjukkan adanya pengembangan teknik pemangkasan sekunder yang berkembang pada masa bercocok tanam. Tipologi yang dihasilkan merupakan alat-alat mikrolit dengan adanya gejala tipe struktur segitiga (mata panah).

4. Adanya perbedaan aktivitas yang berlangsung antara Gua Lawa dengan Ceruk Layah. Gua Lawa yang terletak dekat Kali Areng dimanfaatkan secara multi fungsi, sedangkan Ceruk Layah yang terletak di lereng perbukitan kapur dimanfaatkan untuk pembuatan alat litik.

\section{KEPUSTAKAAN}

Bemmelen, van R.W., 1949. The Geology of Indonesia Vol. I A General Geology of Indonesia and Adjacent Archipelagoes. The Hague : Martinus Nijhoff.

Gibbon, Guy, 1984, Anthropological Archaeology, New York: Columbia University Press

Heekeren, H.R. van., 1972. Stone Age of Indonesia, VKI, The Hague : Martinus Nijhoff.

Nurani, Indah Asikin, 2000, LPA Pola Pemanfaatan Lahan Gua-gua di Kabupaten Ponorogo, Yogyakarta : Balai Arkeologi, belum diterbitkan.

------, 2001, LPA Pola Pemanfaatan Lahan Gua-gua di Kabupaten Ponorogo, Yogyakarta : Balai Arkeologi, belum diterbitkan.

-----, 2002, LPA Pola Pemanfaatan Lahan Gua-gua di Kabupaten Ponorogo, Yogyakarta : Balai Arkeologi, belum diterbitkan. 